\title{
Child abuse in the West Bank of the occupied Palestinian territory (WB/oPt): social and political determinants
}

\author{
Nouh Harsha ${ }^{1,2^{*}} \mathbb{D}$, Margaret A. Lynch ${ }^{3}$ and Rita Giacaman ${ }^{4 *}$
}

\begin{abstract}
Background: Child maltreatment is a global epidemic. It affects morbidity, mortality, social behavior, wellbeing, and quality of life of children. This study aims to assess prevalence of child abuse in the West Bank (WB) of the occupied Palestinian territory (oPt) and to determine some of its social and political associated factors.

Methods: We analyzed secondary data obtained from a cross sectional study conducted on a sample representing Palestinian children on the West Bank and using the International Society for the Prevention of Child Abuse and Neglect (ISPCAN) tool. The ISPCAN Child Abuse Screening Tool for parents (ICAST-P) questionnaire was completed by 1107 Palestinian mothers to estimate physical and emotional child abusive practices at home for children aged 0-12 years. Univariate, bivariate, and multivariate binary logistic regression analyses were performed using the SPSS ${ }^{\circledR}$ version 20 to assess prevalence and predictors of child abuse.

Results: Overall, around 34\% of the West Bank-children were abused by their mothers. Results of the logistic regression analysis indicated that male children, children of younger mothers, children whose fathers were with low levels of education, children whose mothers reported low levels of parental warmth, and children whose parents were exposed to political violence were at greater risk of being abused.

Conclusions: Child abuse is highly prevalent among children of the Palestinian society in the West Bank. Policy makers need to pay more attention to this epidemic. The association between child abuse and political violence found in this study makes a just solution for Palestinians essential for improving the welfare of children and families.
\end{abstract}

Keywords: Child abuse, Physical and emotional abuse, Education levels, West Bank, Parental warmth, Political violence

\section{Background}

In 2008, the Centres for Disease Control and Prevention defined child maltreatment as "Any act or series of acts of commission or omission by a parent or other caregiver that results in harm, potential for harm, or threat of harm to a child" [1]. Commissions refer to child abuse including physical, sexual, and psychological (emotional)

\footnotetext{
*Correspondence: nouhharsha@gmail.com; rita@birzeit.edu

${ }^{1}$ Doctoral School of Health Sciences, University of Debrecen, Debrecen, Hungary

${ }^{4} \mathrm{CPH} / \mathrm{BZU}$, Birzeit, Palestine

Full list of author information is available at the end of the article
}

abuse, and omissions refer to neglect whether physical, emotional, medical, or educational [2].

Child abuse is a global health concern [3-5], occurring in both developing and developed nations $[6,7]$. A systematic review on global prevalence of violence against children in 96 countries reported that over one billion of children had experienced physical, emotional or sexual violence during the year that preceded the survey [8]. Likewise, the United Nations International Children's Emergency Fund (UNICEF) reported that around 300 million children aged 2 to 4 years are subjected to

C C The Author(s). 2020 Open Access This article is licensed under a Creative Commons Attribution 4.0 International License, which permits use, sharing, adaptation, distribution and reproduction in any medium or format, as long as you give appropriate credit to the original author(s) and the source, provide a link to the Creative Commons licence, and indicate if changes were made. The images or other third party material in this article are included in the article's Creative Commons licence, unless indicated otherwise in a credit line to the material. If material is not included in the article's Creative Commons licence and your intended use is not permitted by statutory regulation or exceeds the permitted use, you will need to obtain permission directly from the copyright holder. To view a copy of this licence, visit http://creativecommons.org/licenses/by/4.0/ The Creative Commons Public Domain Dedication waiver (http://creativecommons.org/publicdomain/zero/1.0/) applies to the data made available in this article, unless otherwise stated in a credit line to the data. 
violent disciplines around the world [9]. In the USA, $80 \%$ of the children were spanked by the time they were in the kindergarten [10]. A study conducted in 3 provinces in Turkey on 7540 children reported that $62.7 \%$, and $46.0 \%$ of the children experienced psychological, and physical abuse, respectively [11]. A study on 154 children in Afghanistan concluded that $71 \%$ of the children reported exposure to physical violence [12].

Child maltreatment affects morbidity, mortality, social behavior, wellbeing, and quality of life $[11,13,14]$. Child victimization has been shown to impair physical and mental health [15]. Researchers found a link between parental use of harsh verbal discipline and depressive symptoms, low self-esteem, and academic achievements $[16,17]$. Negative discipline practices such as corporal punishment, yelling, and demonstrating disappointment studied in 6 countries have been shown to be related to internalizing problems (such as anxiety and depression) and externalizing disorders such as aggression regardless of the culture or the country $[18,19]$. In addition, parental aggressiveness and negligence were shown to increase child misbehaviour and hostility [20]. Exposure to child abuse increases risk of smoking, immobility, obesity, diabetes, heart, lung and hepatic diseases [21-25]. A study conducted in Canada on child abuse in early life found a positive association between slapping and spanking children and psychiatric disorders, alcohol addiction, and dependence in later life [26].

Several factors have been shown to influence the prevalence of child abuse. Those include demographics such as age, gender, education $[27,28]$. Family structure, parental conflicts, single mothers, number of children in the family, and parental warmth are important determinants of child maltreatment [29-31]. In addition, parents; economic status, family daily stressors, neighbourhood poverty, and place of residence play a major role in child abuse rates [11, 32]. A systematic review of the literature indicated that children with disabilities are more likely to be abused compared to other children with no disability [33]. In 2010, Euser and colleagues reported that children of refugee families remain at high risk of being abused or maltreated [34]. Furthermore, cultural issues, religious considerations, and ethnicity affect prevalence of violence against children [35, 36]. Indeed, research has shown that parental beliefs, attitude towards domestic violence, exposure of parents to maltreatment in their early childhood, parent's exposure to violence, civil conflicts, presence of armed groups, armed conflicts, and political stress are major determinants of child abuse [37-40].

Political instability and war like conditions have been shown to result in the general deterioration of the quality of life of families including social, economic and developmental aspects $[41,42]$. Children are more susceptible and prone to have greater negative health consequences in such environments [43]. The Palestinian context is characterized by a protracted chronic political conflict extending for several decades [44]. This conflict adds more stressors and burdens on family and parents and as has been reported elsewhere is likely to increase the chance of child abuse [37]. Children living in such an environment are very vulnerable and research on prevention and development of policy guidelines is indispensable and must be considered a top priority [45].

Research on child exposure to violence is relatively rare and inconsistent in the developing countries [46]. A study conducted in 35 low and middle income countries showed that $75 \%$ of the children aged 2 to 14 years were exposed to some forms of violent disciplines [47]. In addition, the study showed that Arabic countries reported higher rates of physical punishment, with Palestine being the most disadvantaged. Indeed, the Palestinian Central Bureau of Statistics (PCBS) conducted a Multiple Indicator Cluster Survey in collaboration with the UNICEF in 2014 and assessed some of the commonly used forms of violence (8 practices were investigated, see Index 1, V 10, 11, 15, 18, 24, 29, 31, 36) and found that $92.2 \%$ of the Palestinian children experienced one or more incidents of physical or psychological abuse in the month that preceded the survey [48]. However, no study has included internationally recognized forms, methods, and practices of child abuse and uncovered major predictors in the Palestinian context.

The theoretical framework upon which this study was designed is based on an ecological model indicating an active role of the human being in the development process and a permanent mutual influence between humans and the environment where they inhabit. This model proposes parenting practices as dependent on the child, parents and the larger socioeconomic and cultural context that eventually affect the human development process and behavior [49]. Given such a framework, the aim of this study is to assess prevalence of child abuse in the West Bank (WB) of the occupied Palestinian territory $(\mathrm{oPt})$ and to determine some of its associated factors. We hypothesize that (1) the prevalence of child abuse in the WB is high and (2) child abuse has social and political determinants.

\section{Methods}

\section{Data source}

This study used secondary data extracted from a larger national cross sectional household survey conducted in Palestine and Qatar to compare child disciplinary methods used by caregivers in both countries using the ICAST-P tool in 2014/2015 [50]. The data is representative of the Palestinian children living in the WB and 
aged 0 to 12 years old. Stratified multistage cluster sampling based on the Palestinian Census Projections of 2007 was used -where the total population of the WB was 2.3 Million- taking size of the different communities of the WB in consideration. Nonresponse rate was 5.6\% (with 3.6\% refusal rate and 2\% absence rate). One thousand five hundred ten mothers were interviewed. Questionnaires with missing data (403 cases) were not included in the final analysis. When we checked, the distribution of the missing cases was generally similar to the distribution of the sample. This was done to ensure that the missing responses were not clustered in a specific area or locality. Data analysis was performed on 1107 respondents.

\section{Instrument}

The International Society for Prevention of Child Abuse and Neglect (ISPCAN) side by side with the UNICEF has developed ISPCAN Child Abuse Screening Tools (ICASTs). Three questionnaires were developed to estimate incidence and prevalence of global violence against children at various stages of their life [51]. In this study, a questionnaire was administered to mothers (ICAST-P) to obtain information on a range of disciplinary (both nonviolent and violent methods including physical and psychological) methods used by parents to discipline their children. This tool which includes the most commonly used disciplinary methods around the globe was used to estimate the extent of abuse of children (aged 0 to 12 years old) at home as reported by their mothers. This tool does not only uncover disciplinary practices the caregivers utilise to discipline their children, but is also a valuable tool to understand and compare the practices across several contexts, cultures, and countries [52].

\section{Outcome measured}

The outcome investigated was child abuse assessed through exposure to physical (moderate or severe) and psychological violence. The mothers were asked about 28 most commonly used practices around the globe and which are included in the ICAST-P tool (Index 1). Internal consistency was checked and Chronbach's alfa was 0.82 indicating very good internal consistency. A six point Likert scale $(1=$ once or twice, $2=3-5$ times, $3=$ $6-10$ times, $4=$ more than 10 times, $5=$ not in the past year, $6=$ never) was used to rate answer of each item. Responses were recoded as 0 (never or not in the past year) and 1 (one to 10 times). The scores were summed up to form a scale then multiplied by100/28 to get a 100 point scale. The scale was recoded as low to moderate levels versus high levels of disciplinary methods. $29.66 \%$ was used as the cutoff point based on the formula mean \pm 0.25 standard deviation [53]. Accordingly, those who experienced 8 or less incidents of violence during the past year were considered as with low to moderate levels of child abuse and those who experienced 9 or more incidents of violence were considered as with high levels of child abuse.

\section{Independent variables}

The Independent variables investigated were the variables proposed by the ISPCAN questionnaire in addition to selected variables deemed necessary to cover in the Palestinian context. Study variables were child's age and gender, Parents age, size of the family, child position in the family, parents' levels of education, type of locality, region, refugee status (Palestinian refugees refer to those who were displaced in 1948 and 1967 and have become residents in West Bank camps since then), child disability, and dependency ratio (no. of children below 14 years old and/or elderly 65 years and above). Parental warmth measured by three questions about child being loved by his parents was also included (Index 2). Chronbach's alfa for this scale was very good (0.84) and the factor analysis showed that the three questions of warmth are loaded on a single variable. A six point Likert scale $(1=$ more than 10 times, $2=$ six to 10 times, $3=$ three to five times, $4=$ once or twice, $5=$ not in the last year, $6=$ never) used to rate the answers on how many times the child was told he was loved was then recoded as 0 (no, never) and 4 (more than 10 times). Answers were summed up for the three variables to form a scale from 0 (minimum warmth) to 12 (maximum warmth). The scale was then converted to 100 by multiplying the scale by $100 / 12$. Using the same formula mean \pm 0.25 standard deviation [53], the scale was categorized into low levels versus moderate to high levels of parental warmth. In addition, we have investigated exposure of the parents to political violence using the two variables: exposure to sound bombs and/or tear gas bombs during the last 12 months. A five point Likert scale $(1=$ yes, extremely, $2=$ yes, a lot, $3=$ yes, moderately, $4=$ yes, a little, $5=$ no, not at all) was used to rate the answers. The scale responses were recoded as 0 (no, not at all) or 1(yes little, moderate, a lot, or extreme). Answers were summed up for the two variables to form a scale with 0 (no. not at all) and 1 (yes). Chronbach's alfa for this scale was (0.84) indicating very good internal consistency.

\section{Statistical analyses}

The outcome was child abuse -physical and emotionalcategorized into two categories low to moderate levels versus high levels. All the independent variables were used as categorical variables in the analysis. Background characteristics were investigated in the univariate analysis. Bivariate analysis to assess the association between the outcome and the independent variables was 
completed using Chi square test. Multivariate binary logistic regression analysis was performed with all the variables that remained significant in the bivariate analysis using SPSS version 20.

\section{Inclusion and exclusion criteria}

Children aged 0 to 12 years and mothers aged 16 years and above were included in the study. The study was specific to children of the WB only.

\section{Results}

Table 1 shows background characteristics of the sample population. $48.1 \%$ of the children were females, $51.3 \%$ were less than 6 years old, $21.9 \%$ of the mothers were 16-29 years old, $9.7 \%$ of the children ranked as first born child in the family, $92.9 \%$ of the families were nuclear, $60.8 \%$ of fathers had less than secondary education, $8.9 \%$ of the mothers were employed, $10.7 \%$ of the children were considered to have one or more disabilities, $30.4 \%$ of the respondents were refugees, $22.0 \%$ of the children experienced low levels of parental warmth, and $41.3 \%$ of the families were exposed to political violence.

Overall, $33.9 \%$ of the children were exposed to high levels of abuse as reported by their mothers (Table 2). Mean level of child abuse was 25.8\% (SD \pm 15.4 ). 36.9\% of the males experienced high levels of abuse compared to $30.6 \%$ of females $(p<.05) .42 .1 \%$ of the children whose mothers aged 16-29years old were exposed to high levels of abuse compared to $12.2 \%$ of those whose mothers aged 50 years and above $(p<.05) .37 .4 \%$ of the children who were first or only children in the family were abused compared to $29.9 \%$ of those who were last in the family $(p<.05) .33 .0 \%$ of the non-disabled children experienced high levels of abuse compared to $41.2 \%$ of the disabled children $(p<.05) .49 .6 \%$ of the children with low levels of parental warmth were abused compared to $29.4 \%$ of the children with moderate to high levels of parental warmth $(p<.05)$, and $30.3 \%$ of the children whose families were not exposed to political violence were abused compared to $38.9 \%$ of those who were exposed to political violence $(p<.05)$.

Table 3 represent results of multivariate binary logistic regression analyses for child abuse. Males were 1.4 times as likely to be abused compared to females $[\mathrm{OR}=1.37$, 95\%CI (1.05-1.78)]. Children of mothers aged 16-29 years were 5 times as likely to be abused compared to those of mothers aged 50 years and above [OR $=4.89$, 95\%CI (1.63-14.65)]. Children whose fathers were with low levels of education were 1.6 times as likely to be abused $[\mathrm{OR}=1.55$, 95\%CI $(1.01-2.38)]$. Children with low levels of parental warmth were twice as likely to be abused $[\mathrm{OR}=2.06,95 \% \mathrm{CI}(1.50-2.83)]$, and children whose parents were exposed to political violence were
1.4 times as likely to be abused $[\mathrm{OR}=1.39$, 95\% CI (1.06-1.82)].

\section{Discussion}

Child abuse is prevalent among children in the WB of the Palestinian society. This high prevalence was reported in a previous study which indicated that $92.2 \%$ of the Palestinian children experienced one or more incidents of violence by their mothers during the month that preceded the survey [48]. Overall, $33.9 \%$ of the children in this study experienced high levels ( 9 or more incidents) of physical and psychological/emotional abuse during the past year as reported by their mothers. This finding is also comparable with other reported studies from Jordan, Syria, Iraq, and Turkey [11, 27, 54].

Our study found that males were more likely to be abused compared to females. This finding is supported by other studies which reported that male children were more likely to be physically [55] and psychologically abused [56, 57]. For instance, our data showed that $61.7 \%$ of the children were spanked (Index 1, V24) with males being more disadvantaged than females (65.6\% for males versus $57.5 \%$ for females). This trend could be attributed to the patriarchal system prevalent in our society as has been reported elsewhere [27]. In 1991, Lytton and Romney in their meta-analysis reported that male children are usually more resistant and express more disobedient bahaviors compared to female children and hence more likely to be physically punished [58]. In addition, some researchers attributed this trend to biological factors and to the gender roles that children are socialized into where boys are given more freedom, autonomy, and power than girls who are treated more strictly and taught to be more obedient than boys early on $[59,60]$. Akmatov investigated child abuse in 28 developing countries and reported that the higher prevalence of child abuse among boys could be attributed to higher expectations from boys since they are seen as the future family's main source of income [61]. No statistically significant differences were detected by child's age in this study.

Younger mothers were more likely to abuse their children compared to older mothers. This finding endorses findings of other studies which provided evidence on this trend $[62,63]$. Researchers attributed this to life experience such as lack of knowledge and experience in child rearing among younger mothers [64]. Indeed, Whitman and colleagues (as reported by Bert and colleagues) concluded that younger and adolescent mothers were more likely to be intolerant, insensitive, and impatient making them more eligible to involve negative discipline practices than older mothers [65]. In addition, as age advances, mothers develop more parenting skills 
Table 1 Descriptive characteristics of the study sample

\begin{tabular}{|c|c|c|}
\hline Variable & Number & Percentage (\%) \\
\hline \multicolumn{3}{|l|}{ Gender } \\
\hline Male & 575 & 51.9 \\
\hline Female & 532 & 48.1 \\
\hline \multicolumn{3}{|l|}{ Child's age (years) } \\
\hline Less than 6 & 568 & 51.3 \\
\hline 6 to 9 & 400 & 36.1 \\
\hline 10 to 12 & 139 & 12.6 \\
\hline \multicolumn{3}{|l|}{ Mother's age } \\
\hline $16-29$ & 242 & 21.9 \\
\hline $30-39$ & 540 & 48.7 \\
\hline $40-49$ & 284 & 25.7 \\
\hline 50 and above & 41 & 3.7 \\
\hline \multicolumn{3}{|l|}{ Father's age } \\
\hline $16-29$ & 61 & 5.5 \\
\hline $30-39$ & 423 & 38.2 \\
\hline $40-49$ & 457 & 41.3 \\
\hline 50 and above & 166 & 15.0 \\
\hline \multicolumn{3}{|l|}{ Family size } \\
\hline Up to 4 & 177 & 16.0 \\
\hline 5 to 7 & 660 & 59.6 \\
\hline 8 and more & 270 & 24.4 \\
\hline \multicolumn{3}{|l|}{ Child's position in family. } \\
\hline First/Only child & 107 & 9.7 \\
\hline Middle child & 325 & 29.4 \\
\hline Last child & 675 & 60.9 \\
\hline \multicolumn{3}{|l|}{ Family structure } \\
\hline Nuclear & 1028 & 92.9 \\
\hline Extended & 79 & 7.1 \\
\hline \multicolumn{3}{|l|}{ Education (mothers) } \\
\hline Below secondary & 648 & 58.5 \\
\hline Secondary & 209 & 18.9. \\
\hline Post-secondary & 250 & 22.6 \\
\hline \multicolumn{3}{|l|}{ Education (father) } \\
\hline Below secondary & 673 & 60.8 \\
\hline Secondary & 194 & 17.5 \\
\hline Post-secondary & 240 & 21.7 \\
\hline \multicolumn{3}{|l|}{ Employment (mother) } \\
\hline Employed & 99 & 8.9 \\
\hline Housewife or unemployed & 1008 & 91.1 \\
\hline \multicolumn{3}{|l|}{ Employment (father) } \\
\hline Laborer & 333 & 30.1 \\
\hline Middle class manager/landowner & 656 & 59.3 \\
\hline Unemployed & 118 & 10.7 \\
\hline
\end{tabular}

Table 1 Descriptive characteristics of the study sample (Continued)

\begin{tabular}{|c|c|c|}
\hline Variable & Number & Percentage $(\%)$ \\
\hline \multicolumn{3}{|c|}{ Number of persons working part-time in household } \\
\hline No body & 931 & 84.1 \\
\hline 1 to 4 persons & 176 & 15.9 \\
\hline \multicolumn{3}{|l|}{ Dependency ratio } \\
\hline No body & 69 & 6.2 \\
\hline 1 to 3 persons & 166 & 15.0 \\
\hline 4 and more & 872 & 78.8 \\
\hline \multicolumn{3}{|l|}{ Child disability } \\
\hline No & 988 & 89.3 \\
\hline Yes & 119 & 10.7 \\
\hline \multicolumn{3}{|l|}{ Locality type } \\
\hline Urban & 412 & 37.2 \\
\hline Rural & 614 & 55.5 \\
\hline Camp & 81 & 7.3 \\
\hline \multicolumn{3}{|l|}{ Region } \\
\hline North WB & 507 & 45.8 \\
\hline Center WB & 252 & 22.8 \\
\hline South WB & 348 & 31.4 \\
\hline \multicolumn{3}{|l|}{ Refugee status } \\
\hline Refugee & 336 & 30.4 \\
\hline Non refugee & 771 & 69.6 \\
\hline \multicolumn{3}{|l|}{ Parental warmth levels } \\
\hline Low & 244 & 22.0 \\
\hline Moderate to high & 863 & 78.0 \\
\hline \multicolumn{3}{|l|}{ Political violence } \\
\hline No & 650 & 58.7 \\
\hline Yes & 457 & 41.3 \\
\hline
\end{tabular}

which is likely to have positive impact on their behavior and attitudes [66].

Education of the father was an important predictor of child abuse. High levels of father's education were associated with less use of harsh disciplinary methods while no effect of mother education was observed. Similar findings were reported in Turkey in the recent years [27]. Indeed, levels of education are important predictors of socioeconomic status of the family [67]. Research has shown that lower family socioeconomic situation, resulting in poverty and economic hardships, is an important precursor of child maltreatment $[68,69]$. On the other hand higher education level with its role in improving socioeconomic status enables people to fulfil their daily needs and respond to demands, relieving stress, and stabilizing the family. In addition education protects parents from involvement in negative bahaviors such as cigarette smoking and alcohol consumption [69-71]. 
Table 2 Child abuse by sociodemographic and political determinants

\begin{tabular}{|c|c|c|c|c|}
\hline Variable (n) & Variable (n) & $\begin{array}{l}\text { Child abuse (\%) } \\
\text { Low to moderate levels }\end{array}$ & $\begin{array}{l}\text { Child abuse (\%) } \\
\text { High levels }\end{array}$ & $\begin{array}{l}\text { Chi square } \\
\text { (P-value) }\end{array}$ \\
\hline \multirow[t]{2}{*}{ Gender (child) } & Male (575) & 63.1 & 36.9 & 0.017 \\
\hline & Female (532) & 69.4 & 30.6 & \\
\hline \multirow[t]{3}{*}{ Children age (years) } & Less than 6 (568) & 65.3 & 34.7 & 0.397 \\
\hline & 6 to $9(400)$ & 65.5 & 34.5 & \\
\hline & 10 to $12(139)$ & 71.2 & 28.8 & \\
\hline \multirow[t]{4}{*}{ Mothers age } & $16-29(242)$ & 57.9 & 42.1 & $<0.001$ \\
\hline & $30-39(540)$ & 64.1 & 35.9 & \\
\hline & $40-49(284)$ & 73.9 & 26.1 & \\
\hline & 50 and above (41) & 87.8 & 12.2 & \\
\hline \multirow[t]{4}{*}{ Fathers age } & $19-29(61)$ & 60.7 & 39.3 & 0.003 \\
\hline & $30-39(423)$ & 60.8 & 39.2 & \\
\hline & $40-49(457)$ & 68.5 & 31.5 & \\
\hline & 50 and above (166) & 75.3 & 24.7 & \\
\hline \multirow[t]{3}{*}{ Child's position in Family } & First/Only child (107) & 62.6 & 37.4 & 0.002 \\
\hline & Middle child (325) & 59.1 & 40.9 & \\
\hline & Last child (675) & 70.1 & 29.9 & \\
\hline \multirow[t]{3}{*}{ Education (father) } & Below secondary (673) & 63.9 & 36.1 & 0.007 \\
\hline & Secondary (194) & 63.4 & 36.6 & \\
\hline & Post-secondary (240) & 74.6 & 25.4 & \\
\hline \multirow[t]{2}{*}{ Number of persons working part-time at household } & No body (931) & 64.8 & 35.2 & 0.017 \\
\hline & 1 to 4 persons (176) & 73.3 & 26.7 & \\
\hline \multirow[t]{3}{*}{ Dependency ratio } & No body (69) & 58.0 & 42.0 & 0.019 \\
\hline & $1-3$ persons (166) & 74.7 & 25.3 & \\
\hline & More than 3 (872) & 65.1 & 34.9 & \\
\hline \multirow[t]{2}{*}{ Child disability } & No (988) & 67.0 & 33.0 & 0.048 \\
\hline & Yes (119) & 58.8 & 41.2 & \\
\hline \multirow[t]{3}{*}{ Locality type } & Urban (412) & 66.0 & 34.0 & 0.030 \\
\hline & Rural (614) & 67.9 & 32.1 & \\
\hline & Camp (81) & 53.1 & 46.9 & \\
\hline \multirow[t]{2}{*}{ Refugee status } & Refugee (336) & 61.3 & 38.7 & 0.016 \\
\hline & Non refugee (771) & 68.2 & 31.8 & \\
\hline \multirow[t]{2}{*}{ Parental warmth } & Low (244) & 50.4 & 49.6 & $<0.001$ \\
\hline & Moderate to high (863) & 70.6 & 29.4 & \\
\hline \multirow[t]{2}{*}{ Political violence } & No (650) & 69.7 & 30.3 & 0.002 \\
\hline & Yes (457) & 61.1 & 38.9 & \\
\hline Overall & & (732) 66.1 & (375) 33.9 & \\
\hline
\end{tabular}

This could be an explanation of why highly educated fathers are less likely to commit child abuse.

Our result showed that Low levels of parental warmth increase risk of child abuse. This finding endorses findings of Wade and Kendler who reported an inverse association between parental warmth and child abuse [72]. This finding is attributed to the fact that parents who show high levels of parental warmth are more likely to utilize peaceful communication and interaction with their children [73] which is well reported to be protective against child abuse $[74,75]$. Better social and emotional child development were reported among parents who showed love, support, and acceptance to their children. In contrast, inferior social and emotional child development were reported for children whose parents exercised punishment and rejection [76]. 
Table 3 Multivariate binary logistic regression analysis for levels of child abuse

\begin{tabular}{|c|c|c|c|c|c|}
\hline \multirow[t]{2}{*}{ Variable } & & \multirow{2}{*}{$\begin{array}{l}\boldsymbol{P} \\
\text { value }\end{array}$} & \multirow{2}{*}{$\begin{array}{l}\text { Adjusted } \\
\text { OR }\end{array}$} & \multicolumn{2}{|c|}{ 95\% C.I. } \\
\hline & & & & Lower & Upper \\
\hline \multirow[t]{2}{*}{ Gender } & Female & & 1 & & \\
\hline & Male & 0.021 & 1.37 & 1.05 & 1.78 \\
\hline \multirow[t]{4}{*}{ Mother's age } & 50 and above & 0.017 & 1 & & \\
\hline & $16-29$ & 0.005 & 4.89 & 1.63 & 14.65 \\
\hline & $30-39$ & 0.015 & 3.64 & 1.28 & 10.31 \\
\hline & $40-49$ & 0.069 & 2.56 & 0.93 & 7.06 \\
\hline \multirow[t]{3}{*}{ Father's education } & Post-secondary & 0.098 & 1 & & \\
\hline & Less than secondary & 0.064 & 1.40 & 0.98 & 1.98 \\
\hline & Secondary & 0.045 & 1.55 & 1.01 & 2.38 \\
\hline \multirow[t]{2}{*}{ Parental warmth } & Moderate to high & & 1 & & \\
\hline & Low & $<0.001$ & 2.06 & 1.50 & 2.83 \\
\hline \multirow[t]{2}{*}{ Exposure to political violence } & No & & 1 & & \\
\hline & Yes & 0.017 & 1.39 & 1.06 & 1.82 \\
\hline
\end{tabular}

Exposure of parents to political violence was associated with increased chances of child abuse. Research has shown that exposure to contextual violence and existence of armed groups in communities were associated with increased violent disciplines such as corporal punishment [37]. In fact, exposure to political violence and conflicts have negative consequences on people's life such as suffering, distress, trauma, general and mental health, family stability and functioning, and wellbeing of the communities in general [77, 78]. The resulting deterioration of social, economic, and political structures has been well reported as increasing the risk of child maltreatment [71, 79]. In addition, Cuartas and colleagues in 2019 reported that exposure to violence and armed conflicts is likely to alter dynamics, social norms, and attitudes towards the use of violent discipline [37].

\section{Study limitations}

Despite being conducted on a regionally representative sample, our study has got some limitations. This is a cross sectional study that elucidates association but not causation. Important variables like parents' wellbeing, distress, and conflict were not investigated. Mothers may have underreported some of the violent practices to avoid pressure from the family and the community. This study did not include Palestinian children of the Gaza Strip.

\section{Study implications}

Children have the right of protection from all forms of violence as has been stipulated by the Convention on the Rights of the Child (CRC) [47]. The findings of this study are very important and provide guidance to policy makers to identify high risk groups among children where preventive interventions are essential and constitute a top priority. Such interventions are necessary for creating an optimum environment for a healthy and safe development of children in the early stage of life so that they can achieve their maximum potential. These interventions should be implemented side by side with the principles of child rights illustrated in the CRC without compromising the capacity of families to exercise the desired harmless forms of child discipline. Providing young mothers with education and support in the use of appropriate rearing practices together with an understanding of the consequences of child abuse could be important steps in preventing violence against children. Those providing the education and support, such as health and social care providers will themselves require training and on-going support. Palestine has ratified the CRC recently and policy makers need to make concerted efforts to protect our future generations. Thus, laws and legislations should be set to ensure an optimum environment for the development and protection of the child. A just political solution to the Palestine question that ends the protracted conflict and exposure to violence is essential if we are to save our children and improve their lives and wellbeing.

\section{Conclusions}

Our results revealed an overall high prevalence of child abuse in the WB of the oPt. The most disadvantaged children were boys, children whose mothers were younger, children whose fathers were less educated, children with low levels of parental nurturing, and children whose parents were exposed to political violence. These findings identify and emphasize the place of social, economic, and political issues as major determinants of family wellbeing and population health. 


\section{Supplementary information}

Supplementary information accompanies this paper at https://doi.org/10. 1186/s12889-020-09251-X.

Additional file 1: Index 1. Physical and emotional child abuse questions (adapted from ICAST-P questionnaire).

Additional file 2: Index 2. Parental nurturing questions (developed by Samia Halileh, a senior Palestinian paediatrician, from her local research and practice).

\section{Abbreviations}

UNICEF: United Nations International Children's Emergency Fund; PCBS: Palestinian Central Bureau of Statistics; WB: West Bank; oPt: Occupied Palestinian territory; ISPCAN: The International Society for Prevention of Child Abuse and Neglect; ICASTs: ISPCAN Child Abuse Screening Tools; ICASTP: ISPCAN Child Abuse Screening Tool (parents version); 95\%Cl: 95\% confidence intervals; OR: Odds ratios; CRC: Convention on the Rights of the Child

\section{Acknowledgements}

Not applicable.

\section{Authors' contributions}

$\mathrm{NH}$ analyzed the data, prepared the methods, results, discussion, and wrote the manuscript. ML participated in data analysis, literature and results presentation, and paper drafting. RG played a major role in data analysis, paper conceptualization along with $\mathrm{NH}$, and supervision of the entire work. All authors read and approved the final manuscript.

\section{Funding}

The original study (National cross sectional household survey conducted in Palestine and Qatar to compare child disciplinary methods used by caregivers in both countries in 2014/2015) was conceptualized and planned by Marcellina Mian, Rita Giacaman, Samia Halileh and Margaret Lynch. It was made possible by NPRP Grant \# 5-240-5-032 from the Qatar Nationa Research Fund (a member of Qatar Foundation). No funding was received for conducting this present study. The statements made herein are solely the responsibility of the authors.

\section{Availability of data and materials}

This study used secondary data extracted from a larger national cross sectional household survey conducted in Palestine and Qatar to compare child disciplinary methods used by caregivers in both countries using the ICAST-P tool in 2014/2015. Two of the authors of this paper (Rita Giacaman and Margaret Lynch) were involved in the original study design. Thus, they have a legal access to the data and no permission or consent was required The data is not available publicly. However, upon a reasonable request, the data can be obtained from the authors.

\section{Ethics approval and consent to participate}

Not applicable.

\section{Consent for publication}

Not applicable.

\section{Competing interests}

"The authors declare that they have no competing interests".

\section{Author details}

${ }^{1}$ Doctoral School of Health Sciences, University of Debrecen, Debrecen, Hungary. ${ }^{2}$ Institute of Community and Public Health, Birzeit University- ICPH/ BZU, Birzeit, Palestine. ${ }^{3}$ Kings College, London, UK. ${ }^{4} \mathrm{ICPH} / \mathrm{BZU}$, Birzeit, Palestine.
Received: 23 March 2020 Accepted: 13 July 2020

Published online: 18 July 2020

\section{References}

1. Leeb RT, Paulozzzi L, Melanson C, Simon TR, Arias I. Child maltreatment surveillance. Uniform definitions for public health and recommended data elements. Atlanta: Centers for Disease Control and Prevention; 2008.

2. Gilbert R, Widom CS, Browne K, Fergusson D, Webb E, Janson S. Burden and consequences of child maltreatment in high-income countries. Lancet. 2009;373(9657):68-81.

3. Stoltenborgh M, Bakermans-Kranenburg MJ, Alink LRA, van ljzendoorn MH. The universality of childhood emotional abuse: a meta-analysis of worldwide prevalence. J Aggress Maltreat Trauma. 2012;21(8):870-90.

4. Krug EG, Mercy JA, Dahlberg LL, Zwi AB. The world report on violence and health. Lancet. 2002;360(9339):1083-8.

5. Wirtz AL, Alvarez C, Guedes AC, Brumana L, Modvar C, Glass N. Violence against children in Latin America and Caribbean countries: a comprehensive review of national health sector efforts in prevention and response. BMC Public Health. 2016;16(1):1006.

6. Rao S, Lux AL. The epidemiology of child maltreatment. Paediatr Child Health. 2012;22(11):459-64

7. Zolotor AJ, Puzia ME. Bans against corporal punishment: a systematic review of the laws, changes in attitudes and behaviours. Child Abuse Rev. 2010; 19(4):229-47.

8. Hillis S, Mercy J, Amobi A, Kress H. Global prevalence of past-year violence against children: a systematic review and minimum estimates. Pediatrics. 2016;137(3):e20154079.

9. UNICEF. Violent discipline, UNICEF data: Monitoring the situation of children and women, 2017. https://data.unicef.org/topic/child-protection/violence/ violent-discipline/. Accessed 26 May 2019.

10. Gershoff ET, Lansford JE, Sexton HR, Davis-Kean P, Sameroff AJ. Longitudinal links between spanking and children's externalizing behaviors in a national sample of white, black, Hispanic, and Asian American families. Child Dev. 2012;83(3):838-43.

11. Sofuoğlu Z, Oral R, Aydın F, Cankardeş S, Kandemirci B, Koç F, et al. Epidemiological study of negative childhood experiences in three provinces of Turkey. Turk Pediatri Ars. 2014;49(1):47-56.

12. O'Leary P, Cameron CM, Lakhani A, Osborne JM, de Souza L, Hope K, et al. Violence against children in Afghanistan: concerns and opportunities for positive change. Child Abuse Negl. 2018;76:95-105.

13. Ma J, Grogan-Kaylor A, Delva J. Behavior problems among adolescents exposed to family and community violence in Chile. Fam Relat. 2016;65(3): 502-16.

14. Gershoff ET. Corporal punishment by parents and associated child behaviors and experiences: a meta-analytic and theoretical review. Psychol Bull. 2002; 128(4):539-79.

15. Turner HA, Finkelhor D, Ormrod R. The effect of lifetime victimization on the mental health of children and adolescents. Soc Sci Med. 2006:62(1):13-27.

16. Wang MT, Kenny S. Longitudinal links between fathers' and mothers' harsh verbal discipline and adolescents' conduct problems and depressive symptoms. Child Dev. 2014;85(3):908-23.

17. Solomon CR, Serres F. Effects of parental verbal aggression on children's self-esteem and school marks. Child Abuse Negl. 1999;23(4):339-51.

18. Gershoff ET, Grogan-Kaylor A, Lansford JE, Chang L, Zelli A, Deater-Deckard $\mathrm{K}$, et al. Parent discipline practices in an international sample: associations with child behaviors and moderation by perceived normativeness. Child Dev. 2010;81(2):487-502.

19. Lansford JE, Malone PS, Dodge KA, Chang L, Chaudhary N, Tapanya S, et al. Children's perceptions of maternal hostility as a mediator of the link between discipline and Children's adjustment in four countries. Int J Behav Dev. 2010;34(5):452-61.

20. Russell A. Positive parenting and Boys' and Girls' misbehaviour during a home observation. Int J Behav Dev. 1996;19(2):291-308.

21. Anda RF, Croft JB, Felitti VJ, Nordenberg D, Giles WH, Williamson DF, et al. Adverse childhood experiences and smoking during adolescence and adulthood. JAMA. 1999;282(17):1652-8

22. Min MO, Minnes S, Kim H, Singer LT. Pathways linking childhood maltreatment and adult physical health. Child Abuse Negl. 2013;37(6):361-73.

23. Williamson DF, Thompson TJ, Anda RF, Dietz WH, Felitti V. Body weight and obesity in adults and self-reported abuse in childhood. Int J Obes Relat Metab Disord. 2002;26(8):1075-82. 
24. Springer KW, Sheridan J, Kuo D, Carnes M. Long-term physical and mental health consequences of childhood physical abuse: results from a large population-based sample of men and women. Child Abuse Negl. 2007; 31(5):517-30.

25. Sweeting JA, Garfin DR, Holman EA, Silver RC. Associations between exposure to childhood bullying and abuse and adulthood outcomes in a representative national U.S. sample. Child Abuse Negl. 2020;101:104048.

26. MacMillan $\mathrm{HL}$, Boyle MH, Wong MY, Duku EK, Fleming JE, Walsh CA. Slapping and spanking in childhood and its association with lifetime prevalence of psychiatric disorders in a general population sample. CMAJ. 1999;161(7):805-9.

27. Sofuoglu Z, Sariyer G, Ataman MG. Child maltreatment in Turkey: comparison of parent and child reports. Cent Eur J Public Health. 2016;24(3): 217-22.

28. Alyahri A, Goodman R. Harsh corporal punishment of Yemeni children: occurrence, type and associations. Child Abuse Negl. 2008;32(8):766-73.

29. Gonzalez MR, Trujillo A, Pereda N. Corporal punishment in rural Colombian families: prevalence, family structure and socio-demographic variables. Child Abuse Negl. 2014;38(5):909-16.

30. Grusec JE, Danyliuk T, Kil H, O'Neill D. Perspectives on parent discipline and child outcomes. Int J Behav Dev. 2017;41(4):465-71.

31. Cluver L, Meinck F, Yakubovich A, Doubt J, Redfern A, Ward C, et al. Reducing child abuse amongst adolescents in low- and middle-income countries: a pre-post trial in South Africa. BMC Public Health. 2016;16(1):567.

32. Beckerman $M$, van Berkel SR, Mesman J, Alink LR. The role of negative parental attributions in the associations between daily stressors, maltreatment history, and harsh and abusive discipline. Child Abuse Negl. 2017;64:109-16.

33. Stalker K, McArthur K. Child abuse, child protection and disabled children: a review of recent research. Child Abuse Rev. 2012;21(1):24-40.

34. Euser EM, van IJzendoorn MH, Prinzie P, Bakermans-Kranenburg MJ. Elevated child maltreatment rates in immigrant families and the role of socioeconomic differences. Child Maltreatment. 2011;16(1):63-73.

35. Petts RJ, Kysar-Moon AE. Child discipline and conservative Protestantism: why the relationship between corporal punishment and child behavior problems may vary by religious context. Rev Relig Res. 2012;54(4):445-68.

36. Berlin LJ, Ispa JM, Fine MA, Malone PS, Brooks-Gunn J, Brady-Smith C, et al. Correlates and consequences of spanking and verbal punishment for lowincome white, african american, and mexican american toddlers. Child Dev. 2009;80(5):1403-20.

37. Cuartas J, Grogan-Kaylor A, Ma J, Castillo B. Civil conflict, domestic violence, and poverty as predictors of corporal punishment in Colombia. Child Abuse Negl. 2019;90:108-19.

38. Miller KE, Jordans MJ. Determinants of Children's mental health in war-torn settings: translating research into action. Curr Psychiatry Rep. 2016;18(6):58.

39. Lakhdir MPA, Nathwani AA, Ali NA, Farooq S, Azam SI, Khaliq A, et al. Intergenerational transmission of child maltreatment: predictors of child emotional maltreatment among 11 to 17 years old children residing in communities of Karachi, Pakistan. Child Abuse Negl. 2019;91:109-15.

40. Ateah CA, Durrant JE. Maternal use of physical punishment in response to child misbehavior: implications for child abuse prevention. Child Abuse Negl. 2005;29(2):169-85.

41. Kondylis F. Conflict displacement and labor market outcomes in post-war Bosnia and Herzegovina. J Dev Econ. 2010;93(2):235-48.

42. Batniji R, Rabaia Y, Nguyen-Gillham V, Giacaman R, Sarraj E, Punamaki RL, et al. Health as human security in the occupied Palestinian territory. Lancet. 2009;373(9669):1133-43.

43. Santa BJ. Impact of war on children and imperative to end war. Croat Med J. 2006;47(6):891-4.

44. Khatib I, Canetti D, Rubin A. Conflict perception: a new scale with evidence from Israel and Palestine. Int J Confl Manag. 2018;29(3):376-97.

45. Stark $L$, Landis $D$. Violence against children in humanitarian settings: a literature review of population-based approaches. Soc Sci Med. 2016;152: 125-37.

46. UNICEF. Child protection monitoring and evaluation reference group, measuring violence against children: inventory and assessment of quantitative studies. New York: Division of Data, Research and Policy; 2014.

47. UNICEF, Child Disciplinary Practices at Home: Evidence from a Range of Low- and Middle-Income Countries, New York, 2010.

48. PCBS. Palestinian Multiple Indicator Cluster Survey 2014, Final report. Ramallah: Palestinian Central Bureau of Statistics; 2015.
49. Schelbe L, Geiger JM. Theoretical frameworks conceptualizing intergenerational transmission of child maltreatment. In: Schelbe L, Geiger JM, editors. Intergenerational transmission of child maltreatment. Cham: Springer International Publishing; 2017. p. 15-24.

50. Kamal M, Halileh S, Dargham S, Alyafei KA, Giacaman R, Imseeh S, et al. Comparing disciplinary methods used by mothers in Palestine and Qatar. Child Abuse Negl. 2018;81:118-27.

51. ISPCAN. International Society for the Prevention of child abuse and neglect, Manual for Administration: The ISPCAN Child Abuse Screening Tool (ICAST). 2015.

52. Runyan DK, Dunne MP, Zolotor AJ. Introduction to the development of the ISPCAN child abuse screening tools. Child Abuse Negl. 2009;33(11):842-5.

53. Pestana MH, Gageiro JM. Data analysis for social sciences: the complementarity of SPSS. 6th ed. Lisbon: Silabo; 2014.

54. United Nations. Children's fund, hidden in plain sight: a statistical analysis of violence against children. New York: UNICEF; 2014

55. Thompson MP, Kingree JB, Desai S. Gender differences in long-term health consequences of physical abuse of children: data from a nationally representative survey. Am J Public Health. 2004;94(4):599-604.

56. Karakurt G, Silver KE. Emotional abuse in intimate relationships: the role of gender and age. Violence Vict. 2013;28(5):804-21.

57. Ba-Saddik ASS, Hattab AS. Emotional abuse towards children by schoolteachers in Aden Governorate, Yemen: A cross-sectional study. BMC Public Health. 2012;12(1):647.

58. Lytton H, Romney DM. Parents' differential socialization of boys and girls: a meta-analysis. Psychol Bull. 1991;109(2):267-96.

59. Abolfotouh MA, El-Bourgy MD, Seif El Din AG, Mehanna AA. Corporal punishment: mother's disciplinary behavior and child's psychological profile in Alexandria, Egypt. J Forensic Nurs. 2009;5(1):5-17.

60. Leaper C, Friedman CK. The Socialization of Gender. Handbook of socialization: Theory and research. New York: Guilford Press; 2007. p. 561-87.

61. Akmatov MK. Child abuse in 28 developing and transitional countries--results from the multiple Indicator cluster surveys. Int J Epidemiol. 2011;40(1):219-27.

62. Stier DM, Leventhal JM, Berg AT, Johnson L, Mezger J. Are children born to young mothers at increased risk of maltreatment? Pediatrics. 1993;91(3):642.

63. Yoon Y, Cederbaum JA, Mennen FE, Traube DE, Chou C-P, Lee JO. Linkage between teen mother's childhood adversity and externalizing behaviors in their children at age 11: three aspects of parenting. Child Abuse Negl. 2019; 88:326-36.

64. Zuravin SJ. Child maltreatment and teenage first births: a relationship mediated by chronic sociodemographic stress? Am J Orthop. 1988;58(1):91-103.

65. Bert SC, Guner BM, Lanzi RG. The influence of maternal history of abuse on parenting knowledge and behavior. Fam Relat. 2009;58(2):176-87.

66. Conger RD, McCarty JA, Yang RK, Lahey BB, Burgess RL. Mother's age as a predictor of observed maternal behavior in three independent samples of families. J Marriage Fam. 1984;46(2):411-24.

67. Crosnoe R, Muller C. Family socioeconomic status, peers, and the Pathto college. Soc Probl. 2014;61(4):602-24.

68. Wong WC, Chen WQ, Goggins WB, Tang CS, Leung PW. Individual, familial and community determinants of child physical abuse among high-school students in China. Soc Sci Med. 2009;68(10):1819-25.

69. Lefebvre R, Fallon B, Van Wert M, Filippelli J. Examining the relationship between economic hardship and child maltreatment using data from the Ontario incidence study of reported child abuse and Neglect-2013 (OIS2013). Behav Sci (Basel). 2017;7(1):6.

70. Hanson MD, Chen E. Socioeconomic status and health behaviors in adolescence: a review of the literature. J Behav Med. 2007;30(3):263.

71. Conger RD, Conger KJ, Martin MJ. Socioeconomic status, family processes, and individual development. J Marriage Fam. 2010;72(3):685-704.

72. Wade TD, Kendler KS. Parent, child, and social correlates of parental discipline style: a retrospective, multi-informant investigation with female twins. Soc Psychiatry Psychiatr Epidemiol. 2001;36(4):177-85.

73. Hoskins DH. Consequences of parenting on adolescent outcomes. Societies. 2014;4(3):506-31.

74. Carroll JE, Gruenewald TL, Taylor SE, Janicki-Deverts D, Matthews KA, Seeman TE. Childhood abuse, parental warmth, and adult multisystem biological risk in the coronary artery risk development in young adults study. Proc Natl Acad Sci U S A. 2013;110(42):17149.

75. Deater-Deckard K, Ivy L, Petrill SA. Maternal warmth moderates the link between physical punishment and child externalizing problems: a parent offspring behavior genetic analysis. Parenting. 2006;6(1):59-78. 
76. Walters J, Stinnett N. Parent-child relationships: a decade review of research. J Marriage Fam. 1971;33(1):70-111.

77. Pedersen D, Tremblay J, Errazuriz C, Gamarra J. The sequelae of political violence: assessing trauma, suffering and dislocation in the Peruvian highlands. Soc Sci Med. 2008:67(2):205-17.

78. Al-Krenawi A, Graham JR, Sehwail MA. Tomorrow's players under occupation: an analysis of the Association of Political Violence with Psychological Functioning and Domestic Violence, Among Palestinian Youth. Am J Orthopsychiatry. 2007;77(3):427-33.

79. Sperry DM, Widom CS. Child abuse and neglect, social support, and psychopathology in adulthood: a prospective investigation. Child Abuse Negl. 2013;37(6):415-25.

\section{Publisher's Note}

Springer Nature remains neutral with regard to jurisdictional claims in published maps and institutional affiliations.

- fast, convenient online submission

- thorough peer review by experienced researchers in your field

- rapid publication on acceptance

- support for research data, including large and complex data types

- gold Open Access which fosters wider collaboration and increased citations

- maximum visibility for your research: over $100 \mathrm{M}$ website views per year

At BMC, research is always in progress.

Learn more biomedcentral.com/submissions 